\title{
The Use of the 'Vulnerability' Label by the Committee on the Elimination of Discrimination Against Women: Protecting or Stigmatizing Women and Girls in the Forced Migration Context?
}

\author{
Veronika Flegar \\ University of Groningen \\ v.l.b.flegar@rug.nl \\ Emma Iedema \\ emmaiedema@hotmail.com
}

\begin{abstract}
This article sheds light on the explicit identification and labelling of forced migrant women and girls as vulnerable and the effect this seems to have on their human rights protection under the Convention on the Elimination of Discrimination Against Women (CEDAW). The article focuses on the principal international body directly concerned with the human rights of women and girls, the Committee on the Elimination of Discrimination Against Women (CEDAW Committee) and combines legal doctrinal analysis with a critical reflection in light of the normative-theoretical notion of universal vulnerability. The notion of universal vulnerability has been suggested to close protection gaps and contribute to a more inclusive human rights framework; yet, the vulnerability label has been criticized as potentially stigmatizing and paternalizing. The article therefore critically assesses whether and to what extent explicit vulnerability references by the CEDAW Committee contribute to the protection and/or stigmatization of forced migrant women and girls. The analysis reveals that the vulnerability label adopted by the CEDAW Committee is not (yet) entirely in line with the universal vulnerability notion's potential for the protection of human rights. Yet, the article suggests that vulnerability references can nevertheless contribute to human rights protection since they help to identify protection priorities and clarify state obligations towards those identified as vulnerable. This positive effect for the protection of
\end{abstract}

(C) VERONIKA FLEGAR AND EMMA IEDEMA, 2019 | DOI:10.1163/23527072-20191021

This is an open access article distributed under the terms of the prevailing CC-BY license at the time of publication. 
human rights is likely to be highest the more attention is being paid to the avoidance of stigmatization.

\section{Keywords}

forced migration - stigmatization - resilience-building - universal vulnerability CEDAW - migrant women and girls - labeling and identification of vulnerability critical legal analysis

\section{Introduction}

Vulnerability is increasingly referred to in the international human rights law discourse. ${ }^{1}$ Previous research suggests that these references to vulnerability can contribute to closing protection gaps and can lead to a more inclusive international human rights law. ${ }^{2}$ However, research also suggests that vulnerability is not clear-cut and that it can be instrumentalized for whichever political ideology one sees fit. As such, vulnerability has been argued to potentially serve as both a distribution criterion and a social control mechanism. ${ }^{3}$ Others have found that vulnerability can be used for conservative as well as socialist aims. ${ }^{4}$ It is for this reason that the present article seeks to propose starting

1 See e.g. Lourdes Peroni and Alexandra Timmer, 'Vulnerable Groups: The Promise of an Emerging Concept in European Human Rights Convention Law', International Journal of Constitutional Law, 11/4: 1056-1085 (2013); Ulrike Brandl and Philip Czech, 'General and Specific Vulnerability of Protection-Seekers in the EU: Is there and Adequate Response to their Needs?' in Francesca Ippolito and Sara Iglesias Sánchez (eds.), Protecting Vulnerable Groups: The European Human Rights Framework, (Oxford: Hart, 2015), pp. 247-270. Veronika Flegar and Marie Veys, 'De Europese Verplichtingen voor Procedurele Waarborgen in de Asielprocedure en de Nederlandse Implementatie vanuit Kwetsbaarheidsperspectief', Journaal Vreemdelingenrecht, 2/11: 28-49 (2017).

2 See e.g. Sylvie da Lomba, 'Vulnerability, Irregular Migrants' Health-Related Rights and the European Court of Human Rights', European Journal of Health Law, 21/4: 339-364 (2014), p. 36o; Martha A. Fineman and Anna Grear (eds.), Vulnerability: Reflections on a New Ethical Foundation for Law and Politics (Farnham: Ashgate, 2013).

3 See e.g. Catherine Brown, The Concept of Vulnerability and its Use in the Care and Control of Young People (PhD Thesis, University of Leeds, 2013).

4 Sean Coyle, 'Vulnerability and the Liberal Order' in Fineman and Grear, Vulnerability, p. 70. 
points for understanding vulnerability in a way that can avoid stigmatization and contribute to the protection of human rights.

This seems a worthwhile endeavor for many contexts and situations in which human rights are repeatedly violated or remain insufficiently realized. One of these areas of concern is the forced migration context. A forced migrant can be understood as someone who has "been forced to move against their will as a result of persecution, conflict, or insecurity". ${ }^{5}$ This very definition of being forced to migrate already disrespects human rights, but, in the course of a forced migrants' journey, the person usually encounters several additional human rights violations. ${ }^{6}$ It is therefore the forced migration context in regard to which this article investigates the question of vulnerability.

Hitherto, most legal research on vulnerability has focused on the European or Inter-American human rights law context while the United Nations' (UN) international human rights law framework has largely been neglected. ${ }^{7}$ This seems surprising considering the fact that several UN treaty bodies, which oversee the implementation of the international human rights law treaties linked to the UN, also frequently refer to the term vulnerability in their work. Preliminary research conducted for this article revealed that one UN treaty body mentions vulnerability particularly prominently in the forced migration context: the Committee on the Elimination of Discrimination Against Women (CEDAW Committee or Committee). This Committee monitors state compliance under the Convention on the Elimination of Discrimination Against Women (CEDAW) - the central framework on the economic, social

5 Elena Fiddian-Qasmiyeh et al., 'Introduction: Refugee and Forced Migration Studies in Transition' in Elena Fiddian-Qasmiyeh et al. (eds.), The Oxford Handbook of Refugee and Forced Migration Studies (Oxford: Oxford University Press, 2014), p. 6.

6 See e.g. Marie-Benedicte Dembour and Tobias Kelly (eds.), Are Human Rights for Migrants? Critical Reflections on the Status of Irregular Migrants in Europe and the United States (Abingdon: Routledge, 2011).

7 For exceptions see e.g. Alexander Morawa, 'Vulnerability as a Concept of International Human Rights Law', Journal of International Relations and Development, 6/2: 139-155 (2003); Audrey Chapman and Benjamin Carbonetti, 'Human Rights Protections for Vulnerable and Disadvantaged Groups: The Contributions of the UN Committee on Economic, Social and Cultural Rights', Human Rights Quarterly, 33/3: 682-732 (2011); Ivona Truscan, The Notion of Vulnerable Groups in International Human Rights Law (PhD Thesis, Graduate Institute Geneva, 2015). 
and cultural rights of women and girls which entered into force in 1981 and currently counts 189 state parties. ${ }^{8}$

This article's investigation of the CEDAW Committee's vulnerability label for forced migrant women and girls has both a theoretical and a practical aim. In theoretical terms, insights into whether and to what extent the vulnerability label for forced migrant women and girls is in line with or contradicts the notion of universal vulnerability can enrich the debate on the extent to which the labelling of persons or groups as vulnerable is stigmatizing and/or can contribute to the protection of human rights. In practical terms, women and girls are often viewed as particularly vulnerable in the forced migration context. The article therefore hopes to contribute to the mitigation of their vulnerability by shedding light on how the law recognizes and attaches state obligations to this vulnerability.

The present article sets out to critically examine the role of the vulnerability label in the CEDAW Committee's work on forced migrant women and girls. The article combines a traditional doctrinal legal analysis of state obligations regarding forced migrant women and girls with a critical legal analysis that questions the extent to which the vulnerability references employed by the CEDAW Committee lead to stigmatization and/or improved human rights protection. The central question is: To what extent does the CEDAW Committee's identification of vulnerability with regard to forced migrant women and girls contribute to the protection of human rights?

The article distinguishes between vulnerability as a label and the 'notion of universal vulnerability'. 'Vulnerability label' refers to the CEDAW's explicit vulnerability references which identify a person or a group of persons as vulnerable (thereby labelling that person or group as being vulnerable). The 'notion of universal vulnerability' refers to the broader theoretical notion of universal vulnerability which this article uses to reflect upon the extent to which the labelling of vulnerability can contribute to the human rights protection of women and girls in the forced migration context.

The article relies on the notion of universal vulnerability as understood by Brian Turner and Martha Fineman since their argument is most instructive in suggesting how attention to vulnerability can avoid stigmatization and

81981 Convention on the Elimination of All Forms of Discrimination against Women (adopted 18 December 1979, entered into force 3 September 1981) UNTS 1249: 13; United Nations Treaty Collection, 'CEDAW', https://treaties.un.org/Pages/ViewDetails.aspx?src=IND\&mtdsg _no=IV-8\&chapter=4\&lang=en, accessed 1 February 2019. 
contribute to the protection of human rights. ${ }^{9}$ The essence of this argument can be summarized as follows: first, in order to avoid a stigmatizing, victimizing or essentializing effect, vulnerability has to be viewed as being both universal and particular. ${ }^{10}$ This precludes the simple reference to vulnerable groups or populations without further clarification of what makes these groups vulnerable and suggests the need for a more individualized and contextualized determination of specific vulnerability factors. ${ }^{11}$ Vulnerability would have to be acknowledged as having both an internal dimension that relates to the embodied nature of vulnerability and an external dimension that relates to the structural disadvantages of the person(s) concerned..$^{12}$ Second, for vulnerability to contribute to the protection of human rights, special attention would have to be paid to the role which societal institutions can play in aggravating or mitigating this vulnerability. The responsibility of the state as builder or at least facilitator of resilience would also have to be recognized. ${ }^{13}$

The article starts by outlining this normative-theoretical argument in more depth. Subsequently, the legal doctrinal analysis focuses on the CEDAw Committee's General Recommendations, its Concluding Observations and its Decisions/Views and first depicts how vulnerability is identified before outlining what legal consequences the Committee seems to attach to this identification. The last section of the article employs the normative-theoretical argument regarding the notion of universal vulnerability to critically reflect upon the work of the Committee with regard to the vulnerability of women and girls in the forced migration context.

The article conducted a systematic search of the documents issued by the Committee in order to identify the most relevant references to vulnerability. ${ }^{14}$ This led to the identification of seven General Recommendations,

Brian S. Turner, Vulnerability and Human Rights (University Park: Pennsylvania State University Press, 2006); Martha A. Fineman, 'Equality, Autonomy, and the Vulnerable Subject in Law and Politics' in Fineman and Grear, Vulnerability, pp. 13-27.

10 Peroni and Timmer, 'Vulnerable Groups', p. 1057. See also e.g. Kate Brown, “'Vulnerability”: Handle with Care', Ethics and Social Welfare, 5/3: 313-321 (2011), p. 316; Fineman, 'Equality, Autonomy and the Vulnerable Subject in Law and Politics', p. 21.

11 Fineman, 'Equality, Autonomy and the Vulnerable Subject in Law and Politics', p. 21.

12 Ibid.

13 Ibid., pp. 24-26.

14 The article used the Office of the High Commissioner for Human Rights' Treaty Body Database and searched CEDAw documents for terms related to vulnerability and migration. Office of the High Commissioner for Human Rights, 'Treaty Body Database', https://tbinternet.ohchr.org/_layouts/treatybodyexternal/TBSearch.aspx?Lang=en, accessed 1 February 2019. 
56 Concluding Observations and two Decisions/Views of the Committee. These documents were subsequently analyzed on the basis of their explicit reference to either the term "vulnerability" or the term "vulnerable" in combination with a forced migration context which meant a reference to either refugees, asylumseekers, internally displaced persons, undocumented migrants or trafficked women or girls. In paying attention to these references the article sought to follow the abovementioned understanding of a forced migrant. These references were subsequently examined in terms of who was identified as vulnerable, the reasons the Committee provided for why this person or group of persons was considered vulnerable and the state obligations which were directly linked to this vulnerability label.

Despite this systematic approach, a number of limitations should be noted. Due to the large amount of Concluding Observations, only the past twelve years were taken into account (2006-2018). In addition, terms such as "marginalized" or "disadvantaged", although sometimes being used in a similar way as vulnerability, were excluded since the article's aim was to focus on the explicit labelling of persons or groups as vulnerable. As with almost any type of categorization, the distinctions made in this article are not always clear-cut but were introduced for the benefit of analytical clarity. As such, in particular the distinction between vulnerability in the country of origin, transit and the receiving country might sometimes overlap. This is, for instance, the case with regard to internally displaced persons who are simultaneously in their country of origin, potentially in transit and, at least temporarily, also in the country that is receiving them. Moreover, the reasons for why a person or group of persons is labelled vulnerable and the obligations flowing from this vulnerability label are not always clearly distinguishable. This is, for instance, the case when the reason for the vulnerability derives from an institutional or legal gap that the Committee recommends to close: this gap might be the reason for the vulnerability while the closing of this gap is the obligation which flows from this vulnerability. In light of these limitations and due to the fact that critical legal analysis remains an interpretive exercise, this article merely offers one possible perspective in order to encourage further debate.

The article finds that the vulnerability label adopted by the CEDAW Committee is not (yet) entirely in line with the universal vulnerability notion's potential for the protection of human rights. Yet, the article suggests that the vulnerability references can nevertheless contribute to human rights protection since they help to identify protection priorities and clarify state obligations towards those identified as vulnerable.

This human rights protection is likely to be highest the more attention is being paid to avoiding stigmatization. Hence, the CEDAW Committee should 
reject the mere labelling of vulnerable groups more consistently and acknowledge the importance of identifying the reasons for why a group is considered vulnerable. In addition, the Committee could emphasize the universal nature of vulnerability more explicitly in order to avoid singling out some human beings as weak or potential victims.

Viewing the issue of forced migration and, in particular, the position of women and girls through the vulnerability lens allows uncovering the issues that should be of absolute priority for states in order to abide by their human rights obligations. Although the CEDAW Committee's understanding of vulnerability mitigation leaves much to be desired, the emphasis which the Committee places on structural deficits and dysfunctions and the role of laws, policies and institutions for the building of resilience seem a promising starting point for an improved protection of the human rights of forced migrant women and girls.

The Notion of Universal Vulnerability - Theory and Conceptualization

This section explains this article's normative perspective on vulnerability as a universal condition. The article chose to rely on the notion of universal vulnerability because this approach is most directly related to human rights and particularly prominent in the legal field. This prominence is likely due to the fact that Fineman suggests the notion of universal vulnerability as a "heuristic tool" for critically examining current laws and policies and argues that, in emphasizing lived experiences, the notion highlights the "human, rather than the rights, part of the human rights trope". ${ }^{15}$ These proposed merits of her approach seem useful for critically reviewing how the vulnerability label can avoid stigmatization and contribute to the protection of the human rights of forced migrant women and girls: is the vulnerability label in line with Fineman's approach? If so, can it indeed emphasize the human part of human rights and what are the merits thereof? Or is the explicit labelling of vulnerability fundamentally different from what Fineman has in mind and therefore not suited for improving human rights protection? In order to answer these questions at the end of this article, the next section explains what this article considers to be the essential elements of Fineman's approach.

The central aspects on the basis of which the work of the CEDAw Committee is reviewed below are the understanding of vulnerability as both universal and particular and the emphasis on the role of state institutions for the

15 Fineman, 'Equality, Autonomy and the Vulnerable Subject in Law and Politics', p. 13. 
building of resilience that can mitigate vulnerability. The section ends with a note of caution about the notion of universal vulnerability.

\subsection{Vulnerability as Universal and Particular}

Understanding the notion of vulnerability as universal builds on the assumption that vulnerability is closely related to the human embodiment. ${ }^{16}$ The concept of human embodiment seems to offer particular substance to universal claims: It highlights that everybody is always vulnerable due to the fact that all humans are inescapably dependent on their body and that this body is continuously susceptible to harm. ${ }^{17}$

Along these lines, Turner establishes that human rights are universal because they are based on the vulnerability which all humans share: ${ }^{18}$ Everyone is united through the fact that all humans can feel humiliation, pain and suffering. ${ }^{19}$ The susceptibility and risk which arise from this vulnerability bind everyone together in a misery that is uniform. ${ }^{20}$ Human rights can therefore be viewed as humanity's response and attempt to mitigate this vulnerability.

Fineman adds to this understanding that vulnerability not only has a universal but also a particular dimension: Vulnerability is universal because the human embodiment makes everyone susceptible to harm and many of these risks cannot be limited or controlled by humans. ${ }^{21}$ Simultaneously, vulnerability is particular as humans "are positioned differently within a web of economic and institutional relationships". ${ }^{22}$ As such, vulnerability is encountered differently by each individual human being depending on the amount and nature of assets a person retains or controls that can help to mitigate vulnerability. ${ }^{23}$ This combination of universal and particular vulnerability forces humans into dependency on internal as well as external circumstances, such as illness or natural disasters respectively. ${ }^{24}$ With this argument Fineman seeks to challenge the assumption of independent, autonomous human beings which often underlies laws and policies and argues that the labelling of vulnerable

\footnotetext{
16 See, e.g., ibid, pp. 1-26; and Turner, Vulnerability and Human Rights.

17 Fineman, 'Equality, Autonomy and the Vulnerable Subject in Law and Politics', p. 20.

18 Turner, Vulnerability and Human Rights, p. 6.

19 Ibid., p. 9.

20 Ibid.

21 Martha A. Fineman, 'The Vulnerable Subject: Anchoring Equality in the Human Condition', Yale Journal of Law and Feminism, 20/1: 1-23 (2008-2009), p. 9.

22 Ibid., p. 10.

23 Ibid.

24 Fineman, 'Equality, Autonomy and the Vulnerable Subject in Law and Politics', p. 21.
} 
groups leads to stigmatization and victimization and is over-inclusive as well as under-inclusive in terms of who is considered vulnerable. ${ }^{25}$

Viewing vulnerability as both universal and particular can diminish the potentially stigmatizing, victimizing or essentializing effect of the vulnerability label because, in understanding human beings as embodied and embedded in a web of complex relationships, it allows for a nuanced excavation of the reasons that make a person or group of persons vulnerable. ${ }^{26}$ This argument precludes simple references to vulnerable groups or populations without further clarification of what makes these groups vulnerable and suggests the need for a more individualized and contextualized identification of the reasons which make a person or group of persons vulnerable. ${ }^{27}$ Ideally, vulnerability would have to be identified by recognizing the interplay between the notion's internal dimension that relates to the human embodiment and its external dimension that relates to the structural disadvantages of the person(s) concerned. ${ }^{28}$

It might seem as if the very focus of this article on the group of forced migrant women and girls contradicts the above argument. However, previous authors suggest that a group-based approach can still have merits for the protection of human rights and that this group-based approach in international human rights law is not necessarily contradicting the notion of universal vulnerability. ${ }^{29}$ It is therefore all the more interesting to shed light on how the vulnerability label employed by the CEDAW Committee might nevertheless avoid stigmatization and contribute to the protection of the human rights of forced migrant women and girls despite this focus on a specific group.

\subsection{Resilience-building as State Response to Vulnerability}

The notion of vulnerability as universal not only raises questions about how to identify vulnerability but also about the moral and legal responsibility once such vulnerability has been identified: what obligations arise towards those identified as vulnerable and who should be responsible? What role can and

25 Ibid., p. 16.

26 Peroni and Timmer, 'Vulnerable Groups', p. 1057. See also e.g. Brown, “Vulnerability”: Handle with Care', p. 316; and Fineman, 'Equality, Autonomy and the Vulnerable Subject in Law and Politics', p. 21.

27 Fineman, 'Equality, Autonomy and the Vulnerable Subject in Law and Politics', p. 21.

28 Ibid.

29 See e.g. Alexandra Timmer, 'A Quiet Revolution: Vulnerability in the European Court of Human Rights' in Fineman and Grear, Vulnerability, pp. 147-170; Veronika Flegar, 'Who is Deemed Vulnerable in the Governance of Migration? Unpacking UnHCR's and Iом's Policy Label for Being Deserving of Protection and Assistance', Asiel- en Migrantenrecht, 8: $374-383$ (2018). 
should human rights play in this respect? From a universal vulnerability perspective, the mitigation of vulnerability and the fostering of resilience is a crucial task for state institutions and require a "responsive state". 30

Turner asserts that individuals are unable to diminish their vulnerability alone, which is why the mitigation of vulnerability requires the establishment of societal institutions. ${ }^{31}$ Human rights are one such societal institution: because of the embodied limitations of an individual's life, humans have to build social and institutional networks of interdependency in order to mitigate the risk of harm..$^{32}$ Human rights can be viewed as part of this network because the law is essential to providing a certain degree of security. ${ }^{33}$

Yet, the mitigation of vulnerability requires more than the mere establishment of human rights and other societal institutions since these institutions cannot properly contribute to resilience-building unless the state protects and supports these structures. ${ }^{34}$ Hence, states do not only have direct obligations to provide assets of resilience to their citizens but to also create the enabling environment in which institutions such as schools, courts, foundations, communities or families operate. ${ }^{35}$

The state is thus essential to forming society and allowing society to function. ${ }^{36}$ This is why the state has a prominent role in the building of resilience in a way that can mitigate vulnerability. Such resilience-building entails that, if existing state institutions exhibit any shortcomings, the state has to intervene to modify the functioning of these institutions in ways that avoid any detrimental effects on society. ${ }^{37}$

To sum up, from a universal vulnerability perspective, the state plays and should play a prominent role in the mitigation of vulnerability. Hence, when vulnerability is identified, special attention should be paid to the role of societal institutions and structural discrepancies for aggravating or mitigating this vulnerability. The responsibility of the state as builder or at least facilitator of resilience should be recognized in this respect in order to clarify who holds which obligations towards those identified as vulnerable. ${ }^{38}$ In so doing, vulnerability

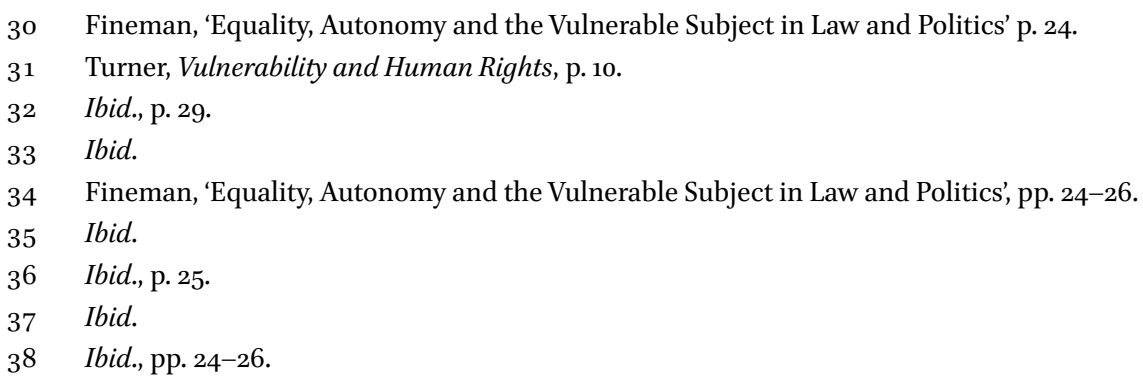


references can move beyond being mere labels and contribute to the protection of the human rights of the person or group of persons identified as vulnerable.

\subsection{A Note of Caution about the Notion of Universal Vulnerability}

The application of the notion of universal vulnerability in the present article does not necessarily mean that the article considers this notion to be the only possible way to look at vulnerability - after all, it is a normative-theoretical ideal that does not necessarily reflect empirical observations. Other normative perspectives on vulnerability exist. ${ }^{39}$ The most prominent 'competitor' of the notion of universal vulnerability seems to be the understanding of vulnerability as related to autonomy. ${ }^{40}$ This, at least partially, contradicts the notion of universal vulnerability in viewing autonomy and vulnerability as complementary rather than as contradicting elements of the human condition. ${ }^{41}$ Going into the details of this debate is beyond the scope of this article but the mere presence of contradicting perspectives requires a short critical reflection on the limitations of the notion of universal vulnerability. Two criticisms are particularly important to consider: a risk of paternalism and a lack of specificity of the notion of universal vulnerability.

As regards the risk of paternalism, the understanding of vulnerability as universal can lead to interventionist policies that threaten individual autonomy. ${ }^{42}$ Fineman's explicit rejection of autonomy raises further concerns in this respect. ${ }^{43}$ Some authors therefore prefer a more nuanced understanding of vulnerability in which vulnerability and autonomy are viewed as situated on a continuum rather than as opposing ideas. ${ }^{44}$

39 See e.g. Kate Brown, Kathryn Ecclestone and Nick Emmel, 'The Many Faces of Vulnerability', Social Policy and Society, 16/3: 497-510 (2017).

40 See Catriona MacKenzie, 'The Importance of Relational Autonomy and Capabilities for an Ethics of Vulnerability' in Catriona MacKenzie, Wendy Rogers and Susan Dodds (eds.), Vulnerability: New Essays in Ethics and Feminist Philosophy (Oxford: Oxford University Press, 2014), pp. 33-59.

41 Ibid. On how this contradicts Fineman's approach see Fineman, 'Equality, Autonomy and the Vulnerable Subject in Law and Politics', pp. 14-21.

42 See, generally, Fineman and Grear, Vulnerability.

43 Catriona MacKenzie, Wendy Rogers and Susan Dodds, 'Introduction: What is Vulnerability, and Why Does it Matter for Moral Theory' in MacKenzie, Rogers and Dodds, Vulnerability, pp. 1-32.

44 MacKenzie, Rogers and Dodds, 'Introduction', pp. 1-32. 
The lack of specificity refers to the fact that the universal vulnerability notion is not defined in relation to a specific context. ${ }^{45}$ Yet, relating specific vulnerabilities to specific contexts allows for uncovering the actual reasons or causes for vulnerability. ${ }^{46}$ Hence, it is necessary to consider not only embodied or structural dimensions at a general level but to view these dimensions as mutually reinforcing, indivisible and relating to a specific situation.

Integrating these criticisms into the notion of universal vulnerability might allow for an even more effective "heuristic tool" for the review of the resiliencebuilding capacities of law and policy. ${ }^{47}$

\section{The CEDAW Committee's Identification of Vulnerability in Relation} to Forced Migrant Women and Girls

This section analyzes the work of the CEDAW Committee with regard to the identification of women and girls as vulnerable in the context of forced migration. The text of CEDAW does not contain explicit rights for women or girls who are forced migrants. Yet, the work of the Committee remains instructive on the issue. The documents issued by the Committee are not formally legally binding but nevertheless remain important interpretive guidelines: by ratifying the CEDAW, state parties commit themselves to comply with the treaty and therefore require authoritative guidance on how to comply. The Committee provides this authoritative guidance and its publications can thus be considered as a legitimate and authoritative source for reviewing the state obligations towards women and girls in the forced migration context. ${ }^{48}$

This section presents the findings on the vulnerability label employed by the Committee with regard to forced migrant women and girls. The findings are structured on the basis of four different phases common to the forced migration process: the situation in the country of origin, the risk of trafficking and the situation during transit, the asylum procedure and the situation in the

45 Nina Kohn, 'Vulnerability Theory and the Role of the Government', Yale Journal of Law and Feminism, 26/1: 1-26 (2014), p. 26.

46 Ibid.

47 Martha Fineman and Anna Grear, 'Introduction: Vulnerability as Heuristic - An Invitation to Future Exploration', in Fineman and Grear, Vulnerability, p. 1.

48 See e.g. Christine Chinkin, 'Sources' in Daniel Moeckli, Sangeeta Shah and Sandesh Sivakuraman (eds.), International Human Rights Law (Oxford: Oxford University Press, 2010), pp. 103-123. 
receiving country ${ }^{49}$ Each subsection is structured by first referring to the Committee's General Recommendations, then to its Concluding Observations and subsequently to its Decisions/Views. It should be noted, however, that the only relevant Decision/Views of the Committee relates to the asylum procedure.

\subsection{Vulnerability in the Country of Origin}

As regards the situation in the country of origin, the CEDAW Committee explicitly recognizes that women and girls are particularly vulnerable to forced displacement..$^{50}$ The Committee seems to consider armed conflict and natural disasters as the most relevant contexts in relation to the vulnerability of women and girls to forced migration. Three General Recommendations and two recent Concluding Observations refer to vulnerability in these situations.

First, with regard to armed conflict, the Committee elaborates upon the access to health care (General Recommendation 24) and to violence and poverty (General Recommendation 30) as the most prominent reasons for the vulnerability of women and girls. General Recommendation 24 directly links the vulnerability of women during armed conflict to the difficulties they encounter when searching for medical assistance and asserts that this especially affects women and girls because of their additional need of sexual and reproductive health services. ${ }^{51}$ Furthermore, the Committee points to the vulnerability of women with mental disabilities which arises from their difficulties in accessing health care during armed conflict and to the general vulnerability of women to mental health risks during armed conflict due to violence, dislocation, poverty, gender discrimination and social deprivation. ${ }^{52}$

In General Recommendation 30 the CEDAW Committee further emphasizes that, generally, vulnerable women in armed conflict face risks in terms of violence, attacks and sexual assault. ${ }^{53}$ However, in this context, the Committee does not specify either who these vulnerable women are or why they are more vulnerable than other women. In a different instance, the Committee is more explicit and mentions several reasons which can make women vulnerable

49 These four stages are also identified by the Committee in CEDAw, General Recommendation 32 on the Gender-related Dimensions of Refugee Status, Asylum, Nationality and Statelessness of Women, CEDAW/C/GC/32, 5 November 2014.

50 CEDAw, General Recommendation 30 on Women in Conflict Prevention, Conflict and PostConflict Situations, CEDAW/C/GC/30, 1 November 2013, para. 53.

CEDAW, General Recommendation 24 on Article 12 of the Convention (Women and Health), A/54/38/Rev.1, 1999, para. 25.

52 Ibid.

53 CEDAW, General Recommendation 30, para. 36. 
to violence and exploitation during armed conflict by increasing their inequality and poverty, namely the exclusion from decision-making processes, poor reproductive health care, unequal access to education, training and income generation and poor infrastructure and camp layout. ${ }^{54}$ The Committee also emphasizes the importance of protecting the poor and argues that, during war, vulnerable groups of women are affected the most by economic hardship and the lack of employment. ${ }^{55}$

In addition to these statements on armed conflict in the General Recommendations, two recent Concluding Observations emphasize the effects that armed conflict can have on the vulnerability of women. The Concluding Observations on Myanmar underline the vulnerability of women from minority groups to forced evictions due to the lack of comprehensive laws guaranteeing protection. ${ }^{56}$ The Concluding Observations on Armenia highlight the vulnerable situation of internally displaced women and girls especially in terms of their access to housing, health, education, employment and their protection from violence. ${ }^{57}$

Second, in the context of natural disasters and climate change, the CEDAw Committee relates the vulnerability of women and girls primarily to inequality issues. As such, General Recommendation 27 states that women are particularly vulnerable to climate change if their access to decision-making processes and resources is limited. ${ }^{58}$ The Committee elaborates that, during natural disasters, women (and especially older women) are particularly disadvantaged due to their physical ability, age, gender, physiological differences, social norms and roles and the unequal distribution of resources and aid as a consequence of social hierarchies. ${ }^{59}$

The table below summarizes the reasons related to the situation in the country of origin which the Committee considers to be conducive to the vulnerability of women and girls to forced displacement Table 1.

\footnotetext{
$54 \quad$ Ibid., para. 54.

$55 \quad$ Ibid., para. 51.

56 CEDAW, Concluding Observations: Myanmar, CEDAW/C/MMR/CO/4-5, 25 July 2016, para. $14(\mathrm{e})$.

57 CEDAW, Concluding Observations: Armenia, CEDAW/C/ARM/CO/5-6, 25 November 2016, para. 32 .

$5^{8}$ CEDAW, General Recommendation 27 on Older Women and Protection of their Human Rights, CEDAW/C/GC/27, 16 December 2010, para. 25 .

Ibid.
} 
TABLE 1 Vulnerability in the Country of Origin

\begin{tabular}{|c|c|c|c|}
\hline $\begin{array}{l}\text { Vulnerability } \\
\text { Context }\end{array}$ & Source & $\begin{array}{l}\text { Vulnerable } \\
\text { Groups }\end{array}$ & Reasons for Vulnerability \\
\hline \multirow[t]{6}{*}{$\begin{array}{l}\text { Armed } \\
\text { Conflict }\end{array}$} & \multirow[t]{4}{*}{$\begin{array}{l}\text { General Recom- } \\
\text { mendations }\end{array}$} & $\begin{array}{l}\text { Women and } \\
\text { girls in conflict } \\
\text { areas }\end{array}$ & $\begin{array}{l}\text { - Due to the difficulties they encounter } \\
\text { when searching for medical assistance and } \\
\text { the limited access to health care in conflict } \\
\text { areas, which affects especially women and } \\
\text { girls because of their extra need of sexual } \\
\text { and reproductive health services. } \\
\text { - Due to the vulnerability to mental health } \\
\text { risks resulting from violence, dislocation, } \\
\text { poverty, gender discrimination and social } \\
\text { deprivation. }\end{array}$ \\
\hline & & $\begin{array}{l}\text { Women } \\
\text { with mental } \\
\text { disabilities }\end{array}$ & $\begin{array}{l}\text { Due to difficulties in accessing } \\
\text { health care during armed conflict. }\end{array}$ \\
\hline & & $\begin{array}{l}\text { Displaced } \\
\text { women }\end{array}$ & $\begin{array}{l}\text { Due to poverty and inequality resulting } \\
\text { from the exclusion from decision-making } \\
\text { processes, poor reproductive health care, } \\
\text { unequal access to education, training and } \\
\text { income generation and poor infrastructure } \\
\text { and camp layout. }\end{array}$ \\
\hline & & $\begin{array}{l}\text { Vulnerable } \\
\text { groups of } \\
\text { women }\end{array}$ & $\begin{array}{l}\text { Due to being affected most by economic } \\
\text { hardship and the lack of employment. }\end{array}$ \\
\hline & \multirow[t]{2}{*}{$\begin{array}{l}\text { Concluding } \\
\text { Observations }\end{array}$} & $\begin{array}{l}\text { Women } \\
\text { belonging to } \\
\text { ethnic minority } \\
\text { groups }\end{array}$ & $\begin{array}{l}\text { Due to the lack of comprehensive laws } \\
\text { guaranteeing protection against forced } \\
\text { eviction. }\end{array}$ \\
\hline & & $\begin{array}{l}\text { Internally } \\
\text { displaced } \\
\text { women }\end{array}$ & $\begin{array}{l}\text { Due to lack of access to education, employ- } \\
\text { ment, health and housing and protection } \\
\text { from all forms of violence. }\end{array}$ \\
\hline $\begin{array}{l}\text { 'Natural' } \\
\text { Disasters }\end{array}$ & $\begin{array}{l}\text { General Recom- } \\
\text { mendations }\end{array}$ & All women & $\begin{array}{l}\text { Due to limited access to resources and } \\
\text { decision-making processes. }\end{array}$ \\
\hline $\begin{array}{l}\text { and Climate } \\
\text { Change }\end{array}$ & $\begin{array}{l}\text { General Recom- } \\
\text { mendations }\end{array}$ & $\begin{array}{l}\text { All women } \\
\text { and especially } \\
\text { older women }\end{array}$ & $\begin{array}{l}\text { Due to their physical ability, age, gender, phys- } \\
\text { iological differences, social norms and roles } \\
\text { and the unequal distribution of resources and } \\
\text { aid as a consequence of social hierarchies. }\end{array}$ \\
\hline
\end{tabular}


This section revealed that the CEDAW Committee mentions several reasons why women and girls are considered to be particularly vulnerable in the country of origin. In some instances, the Committee simply finds them to be vulnerable per se due to their gender. However, in order instances, the Committee does not refer to everyone as vulnerable but seems to introduce a gradation of vulnerability, meaning that some persons or groups are even more vulnerable than others. For instance, all women are vulnerable to mental health issues during armed conflict but persons with mental disabilities are even more vulnerable. Similarly, all women are considered to be vulnerable during natural disasters because of limited access to resources and decision-making processes but elderly women are thought to be even more vulnerable.

In addition, the CEDAW Committee rarely seems to consider vulnerability as such but rather links it to a specific issue such as health issues or material deprivation. While the health issues seem mostly related to women-specific reproductive issues, other aspects of vulnerability are clearly linked to structural marginalization, discrimination or the lack of adequate protection from the state.

\subsection{Vulnerability to Trafficking in the Country of Origin and during Transit}

The CEDAw Committee also calls attention to the consequences which the vulnerabilities of women and girls during armed conflict and natural disasters can have on trafficking and therefore on the transit phase of the migration process. One General Recommendation and twelve Concluding Observations were found to be relevant in this respect.

General Recommendation 30 recognizes that women and girls fleeing conflict zones can encounter difficulties during flight and forced displacement and acknowledges that this process has gender-specific aspects. ${ }^{60}$ As such, the Committee asserts that due to the precarious situation in conflict-affected areas, women and girls are considered to be more vulnerable to trafficking, exploitation and violence. ${ }^{61}$ Migration policies that are restrictive, discriminatory and/or sex-specific are also mentioned as contributing to women's vulnerability to exploitation and trafficking. ${ }^{62}$

Several Concluding Observations also refer to the vulnerability of women and girls to trafficking. Concluding Observations on Saudi Arabia, for instance, recognize the vulnerability of refugee, asylum-seeking and undocumented migrant women and girls to human trafficking but does not provide any elaboration

\footnotetext{
6o CEDAW, General Recommendation 30, para. 40.

61 Ibid., paras. 40 and 53.

62 Ibid., para. 40.
} 
in that respect. ${ }^{63}$ Several other Concluding Observations seem particularly concerned with the gender-specific vulnerability of refugee and migrant women to trafficking but do not further clarify the reasons for this vulnerability. ${ }^{64}$

Yet, other Concluding Observations are more elaborate and identify a number of reasons for the vulnerability of women and girls to trafficking. Accordingly, several Concluding Observations mention poverty and the need of many women and girls to provide support to their families as important reasons for their vulnerability to trafficking. ${ }^{65}$ In the context of Myanmar, the Committee considers movement restrictions and lacking essential services as particularly conducive to the vulnerability of women and girls to trafficking and smuggling. ${ }^{66}$ In addition, Concluding Observations on China find that discrimination against migrant women increases the vulnerability to trafficking since it obstructs legal pathways to migration or livelihood opportunities for women and girls by denying access to the necessary documents or employment opportunities. ${ }^{67}$ Several Concluding Observations also refer to a precarious migration status, to having been rejected as an asylum seeker and to previous internal displacement as aggravating factors for the vulnerability to trafficking. ${ }^{68}$

Aside from the vulnerability to trafficking, several Concluding Observations identify trafficking itself as a reason for the vulnerability of women and girls. As such, the Concluding Observations on Cambodia raise concerns about the vulnerability of trafficked women to infection with HIV/AIDs. ${ }^{69}$ In addition, the Concluding Observations on China point to trafficking as potentially leading to sexual exploitation, abuse, forced marriage and virtual slavery. ${ }^{70}$

63 CEDAW, Concluding Observations: Saudi Arabia, CEDAW/C/SAU/CO/2, 8 April 2008, para. 24 .

64 CEDAw, Concluding Observations: Djibouti, CEDAW/C/DJI/CO/1-3, 2 August 2011, para. 22; CEDAW, Concluding Observations: Bolivia, CEDAW/C/BOL/CO/5-6, 28 July 2015, para. 2o(e); and CEDAW, Concluding Observations: Montenegro, CEDAW/C/MNE/CO/2, 24 July 2017, para. 24(b).

65 CEDAw, Concluding Observations: Azerbaijan, CEDAW/C/AZE/CO/3, 2 February 2007, para. 20; CEDAW, Concluding Observations: Mozambique, CEDAW/C/MOZ/CO/2, 11 June 2007, para. 27; CEDAW, Concluding Observations: Nigeria, CEDAW/C/NGA/CO/7-8, 24 July 2017, para. 27(b); and CEDAW, Concluding Observations: Liberia, CEDAW/C/LBR/CO/7-8, 24 November 2015, para. 27.

66 CEDAw, Concluding Observations: Myanmar, para. 44(f).

67 CEDAw, Concluding Observations: China, CEDAW/C/CHN/6, 25 August 20o6, para. 33.

68 Ibid.; CEDAW, Concluding Observations: Norway, CEDAW/C/NOR/CO/9, 22 November 2017, para. 26(e); CEDAW, Concluding Observations: Guatemala, CEDAW/C/GTM/CO/8-9, 22 November 2017, para. 24(c).

69 CEDAW, Concluding Observations: Cambodia, CEDAW/C/KHM/CO/3, 25 January 2006, para. 19.

$70 \quad$ CEDAW, Concluding Observations: China, para. 33. 
The table below summarizes the Committee's understanding of the vulnerability of women and girls in relation to trafficking Table 2.

This section illustrated that the CEDAW Committee's most relevant consideration in relation to the vulnerability of forced migrant women and girls

TABLE 2 Vulnerability To and Resulting from Trafficking

\begin{tabular}{|c|c|c|c|}
\hline $\begin{array}{l}\text { Vulnerability } \\
\text { Context }\end{array}$ & Source & $\begin{array}{l}\text { Vulnerable } \\
\text { Groups }\end{array}$ & Reasons for Vulnerability \\
\hline \multirow[t]{5}{*}{$\begin{array}{l}\text { Vulnerability } \\
\text { to Trafficking }\end{array}$} & $\begin{array}{l}\text { General } \\
\text { Recommendations }\end{array}$ & $\begin{array}{l}\text { Women and girls } \\
\text { fleeing conflict } \\
\text { zones }\end{array}$ & $\begin{array}{l}\text { Due to gender-specific aspects, } \\
\text { the precarious situation in } \\
\text { conflict-affected areas and } \\
\text { discriminatory migration policies. }\end{array}$ \\
\hline & $\begin{array}{l}\text { Concluding } \\
\text { Observations }\end{array}$ & $\begin{array}{l}\text { Refugees, } \\
\text { asylum-seeking } \\
\text { and undocu- } \\
\text { mented migrant } \\
\text { women and girls }\end{array}$ & Due to their gender. \\
\hline & & Women and girls & $\begin{array}{l}\text { Due to poverty and the need to } \\
\text { provide support to their families. }\end{array}$ \\
\hline & & Migrant women & $\begin{array}{l}\text { - Due to discrimination against mi- } \\
\text { grant women since it obstructs legal } \\
\text { pathways to migration or livelihood } \\
\text { opportunities for women and girls by } \\
\text { denying access to the necessary docu- } \\
\text { ments or employment opportunities. } \\
\text { - Due to a precarious migration status. } \\
\text { - Due to having been rejected as } \\
\text { asylum seeker. } \\
\text { - Due to previous internal } \\
\text { displacement. }\end{array}$ \\
\hline & & Women and girls & $\begin{array}{l}\text { - Due to lack of basic services and } \\
\text { movement restrictions. }\end{array}$ \\
\hline Vulnerability & Concluding & Trafficked women & - Due to the risk of infection with \\
\hline resulting from & Observations & & HIV/AIDS. \\
\hline Trafficking & & & $\begin{array}{l}\text { - Due to the risk of sexual exploitation, } \\
\text { abuse, forced marriage, and virtual } \\
\text { slavery. }\end{array}$ \\
\hline
\end{tabular}


during the transit phase of migration is trafficking. In this respect, one can distinguish the vulnerability to trafficking and the vulnerability resulting from trafficking. While all women and girls are considered to be potentially vulnerable to trafficking due to poverty in combination with their gender, migrant women are identified as particularly vulnerable due to discrimination and potentially precarious migration statuses. Hence, similar to its understanding of vulnerability in the country of origin, the Committee seems to view vulnerability as a question of gradation: some women and girls are vulnerable but some of these are even more vulnerable than others. As regards the vulnerability resulting from trafficking, the Committee does not distinguish in any way but considers all victims of trafficking to be vulnerable due to the risk of HIV/AIDS, sexual exploitation and abuse. Similar to the reasons for vulnerability in the country of origin, the Committee appears to identify both the gender of women and, more prominently, structural issues (e.g. discrimination, precarity and exploitation) as the main reasons for the vulnerability of forced migrant women and girls during transit.

\subsection{Vulnerability during the Asylum Procedure}

The CEDAW Committee also labels forced migrant women and girls as vulnerable during the asylum procedure. One General Recommendation, four Concluding Observations and one Decision/Views are particularly relevant in this respect.

General Recommendation $3^{2}$ considers women or girls who have experienced sexual abuse, trauma or torture as vulnerable during the asylum procedure. ${ }^{71}$ Yet, although the Committee highlights gender-related issues during the asylum procedure, it does not clarify why and to what extent women are considered vulnerable in this regard. ${ }^{72}$ Similarly, several Concluding Observations refer to the vulnerability of women and girls during the asylum procedure but none of them elucidates on which factors contribute to this vulnerability. ${ }^{73}$

The vulnerability of female asylum seekers during the asylum procedure is also discussed in the CEDAW Committee's Views. In M.P.W.v. Canada, a female asylum-seeker claimed that she had fallen victim to gender-based violence in

\footnotetext{
71 CEDAW, General Recommendation 32, para. 34.

$72 \quad$ Ibid.

73 CEDAW, Concluding Observations: Argentina, CEDAW/C/ARG/CO/6, 16 August 2010, para. 45; CEDAW, Concluding Observations: Nepal, CEDAW/C/NPL/CO/4-5, 11 August 2011, para. 41; CEDAW, Concluding Observations: Belgium, CEDAW/C/BEL/CO/6, 7 November 2008, para. 27; CEDAW, Concluding Observations: Italy, CEDAW/C/ITA/CO/7, 24 July 2017, para. $15(a)$.
} 
her country of origin. ${ }^{74}$ Her asylum application was rejected by the Canadian authorities. According to the applicant, Canada had failed to take her situation as a vulnerable woman into account when considering her asylum application. ${ }^{75}$ Yet, since the asylum seeker had already moved to Mexico by the time the Committee considered the complaint, the application was declared inadmissible and the applicant's claim of vulnerability as a victim to gender-based violence was not examined by the Committee.

In its similar Views in Zhen Zhen Zheng v. the Netherlands, the Committee dealt with the issue of a rejected asylum application by a woman who had been a victim of human trafficking. In her claim to the Committee, the applicant stated that the fact that she had turned to the Dutch authorities had made her vulnerable to human trafficking. ${ }^{76}$ The communication was again declared inadmissible since the national remedies had not yet been exhausted. The reasons contributing to the applicant's vulnerability were not further discussed.

Hence, hitherto, the Committee has not in-depth elaborated upon the vulnerability of women and girls during the asylum procedure. Instead, the Committee merely considers women and girls, and especially women and girls who have experienced sexual abuse, trauma or torture as vulnerable. While there thus seems to be a gradation of some women and girls being considered as more vulnerable than others, no further explanatory factors or reasons for this vulnerability are provided.

\subsection{Vulnerability in the Receiving Country}

Lastly, beyond the asylum procedure, the CEDAW Committee also labels forced migrant women and girls as vulnerable in the receiving country more generally. Four General Recommendations and 14 Concluding Observations appear to be relevant in this respect.

Several General Recommendations recognize that during the stay in the receiving country, a refugee, asylum-seeker or migrant woman can be particularly vulnerable. Statelessness and the discrimination of stateless women are mentioned as specific reasons for vulnerability in this context. ${ }^{77}$ Moreover, the

74 CEDAW, M.P.W. v. Canada, Communication No. 25/2010, 13 April 2012, para. 3.1.

75 Ibid., para. 3.6.

$76 \quad$ Ibid., para. $3 \cdot 5$.

77 CEDAW, General Recommendation 32, para. 58 . This statement is strengthened by the position the Committee takes in General Recommendation 28, where the Committee considers discrimination of the rights of undocumented migrants a violation of article two of the CEDAW; CEDAW, General Recommendation 28 on the Core Obligations of States Parties under Article 2 of the Convention on the Elimination of All Forms of Discrimination against Women, CEDAW/C/GC/28, 16 December 2010, para. 31. 
Committee outlines the reasons for why migrant women are labelled as vulnerable in the receiving country as related to the discrimination they might face in accessing justice, social security, education, legal documents, housing, education and employment and the lack of adequate sexual, reproductive and mental health services. ${ }^{78}$ In addition, the Committee specifically identifies living in urban centers in developing countries as a reason that can make migrant women vulnerable with regard to potential climate change impacts. ${ }^{79}$

One human rights issue in the context of which the General Recommendations prominently mention the vulnerability of forced migrant women and girls in the receiving country is the access to education. As such, refugee, asylum seeking, stateless, undocumented, internally displaced and migrant women and girls are considered vulnerable to exclusion from education due to their exposure to multiple and intersecting forms of discrimination. ${ }^{80}$ Specifically in the camp context, this vulnerability can be caused by irrelevant curricula, teaching being conducted only in the majority language, the risk of poverty, stigma and violence, the lack of or limited capacity of schools, the loss of human resources and physical infrastructure, the loss of the documentation needed for enrollment and, specifically for girls, the insecurity of camps which can cause parents to keep their daughters at home. ${ }^{81}$

Concluding Observations refer to the vulnerability of forced migrant women and girls particularly prominently with regard to the receiving country. The CEDAW Committee identifies vulnerability due to country-specific situations, such as with regard to the precarious status of North Korean migrant women in China ${ }^{82}$ or of undocumented migrants as a vulnerable group in Libya. ${ }^{83} \mathrm{In}$ other instances, the vulnerability of unregistered and undocumented women is recognized in general. ${ }^{84}$ In those instances the Committee does not seem to elaborate upon the reasons contributing to this vulnerability.

The Concluding Observations on Ecuador, on the other hand, list a number of risks to which undocumented migrants are exposed and which increase their general vulnerability: abusive work and living conditions,

78 CEDAW, General Recommendation 37 on Gender-related Dimensions of Disaster Risk Reduction in the Context of Climate Change, CEDAW/C/GC/37, 7 February 2018, para. 75.

79 Ibid.

80 CEDAW, General Recommendation 36 on the Right of Girls and Women to Education, CEDAW/C/GC/36, 27 November 2017, paras. 40-42.

$81 \quad$ Ibid.

82 CEDAW, Concluding Observations: China, para. 34.

83 CEDAW, Concluding Observations: Libya, CEDAW/C/LBY/CO/5, 6 February 2009, para. 25.

84 CEDAW, Concluding Observations: Serbia, CEDAW/C/SCG/CO/1, 11 June 2007, para. 27, CEDAW, Concluding Observations: Ecuador, CEDAW/C/ECU/7, 7 November 2008, para. 27. 
gender-based violence, limited access to health care and the violation of the non-refoulement principle. ${ }^{85}$ Moreover, the Concluding Observations assert that asylum-seeking women can be pushed into the informal economy due to discrimination, which can then lead to sexual exploitation. ${ }^{86}$ Other Concluding Observations identify reasons for the vulnerability of forced migrant women and girls in relation to a specific issue at stake.

Several Concluding Observations link this vulnerability to poverty and economic and social rights violations. As such, the Committee repeatedly emphasizes that cuts in social assistance schemes can negatively impact the rights of vulnerable groups of women such as immigrant women. ${ }^{87}$ The Concluding Observations on Austria specifically assert that female migrants, refugees and asylum-seekers are generally vulnerable to poverty but that this can be aggravated by a lack of access to social services. ${ }^{88}$ Several Concluding Observations label refugee and internally displaced women and girls as vulnerable with regard to the access to economic, social and cultural rights because they suffer from discrimination with regard to access to health care, employment, education and social benefits. ${ }^{89}$ Furthermore, the Concluding Observations on Cyprus note that refugee, asylum-seeking and displaced women are vulnerable due to multiple forms of discrimination, stereotyping and difficulties in obtaining employment and accessing social services. ${ }^{90}$

The Committee recognizes that migrant women can be in a vulnerable situation because of the difficulties they encounter with regard to obtaining a residence permit and several Concluding Observations refer to the vulnerability of female migrants, refugees and asylum-seekers to domestic violence ${ }^{91} \mathrm{In}$ addition, the vulnerability of refugee women and girls is linked to problematic

85 CEDAW, Concluding Observations: Ecuador, para. 26.

86 Ibid., para. 22.

87 CEDAW, Concluding Observations: Canada, CEDAW/C/CAN/CO/7, 7 November 2008, para. 13; CEDAW, Concluding Observations: Germany, CEDAW/C/DEU/CO/7-8, 9 March 2017, para. 39(a).

88 CEDAW, Concluding Observations: Austria, CEDAW/C/AUT/6, 2 February 2007, para. 29.

89 CEDAW, Concluding Observations Lebanon, CEDAW/C/LBN/CO/3, 8 April 2008, para. 40; CEDAW, Concluding Observations: Rwanda, CEDAW/C/RWA/CO/7-9, 9 March 2017, para .32(f); CEDAW, Concluding Observations:Armenia,CEDAW/C/ARM/CO/4/Rev.1, 2 February 2009, para. 36 .

90 CEDAW, Concluding Observations: Cyprus, CEDAW/C/CYP/CO/5, 30 May 2006, para. 31.

91 CEDAW, Concluding Observations: Austria, para. 29; CEDAW, 2017 Concluding Observations: Germany, para. 59; CEDAW, Concluding Observations: Sweden, CEDAW/C/SWE/CO/7, 8 April 2008, para. 38 . 
reception and detention conditions caused by difficulties in accessing essential services as well as by concerns for their safety. ${ }^{92}$

The table below summarizes the CEDAW Committee's reasons for considering forced migrant women and girls as vulnerable in the receiving country Table 3 .

TABLE 3 Vulnerability in the Receiving Country

Vulnerability Source $\quad$ Vulnerable Groups Reasons for Vulnerability
Context

\begin{tabular}{|c|c|c|c|}
\hline \multirow[t]{3}{*}{$\begin{array}{l}\text { Stay in the } \\
\text { Receiving } \\
\text { Country }\end{array}$} & $\begin{array}{l}\text { General } \\
\text { Recommendations }\end{array}$ & $\begin{array}{l}\text { Refugee, asylum } \\
\text { seeker or migrant } \\
\text { women }\end{array}$ & - \\
\hline & & Stateless women & $\begin{array}{l}\text { Due to discrimination with regard to } \\
\text { nationality rights. }\end{array}$ \\
\hline & & Migrant women & $\begin{array}{l}\text { Due to lack of adequate sexual, repro- } \\
\text { ductive and mental health services } \\
\text { as well as discrimination in accessing } \\
\text { employment, social security, educa- } \\
\text { tion, housing, legal documents such } \\
\text { as birth or marriage certificates and } \\
\text { justice. }\end{array}$ \\
\hline $\begin{array}{l}\text { Climate } \\
\text { Change }\end{array}$ & & Migrant women & $\begin{array}{l}\text { Due to living in urban centers in } \\
\text { developing countries. }\end{array}$ \\
\hline Education & & $\begin{array}{l}\text { Refugee, asylum } \\
\text { seeking, stateless, } \\
\text { undocumented, } \\
\text { internally dis- } \\
\text { placed and migrant } \\
\text { women and girls }\end{array}$ & $\begin{array}{l}\text { Due to multiple forms of discrimina- } \\
\text { tion", a lack of relevance of the cur- } \\
\text { riculum, teaching conducted only in } \\
\text { the majority language, the exposure } \\
\text { to violence, stigma or poverty, camps } \\
\text { with no schools or makeshift schools } \\
\text { with limited capacity, the loss of hu- } \\
\text { man resources and physical infra- } \\
\text { structure, the loss of the documen- } \\
\text { tation needed for enrollment and, } \\
\text { specifically for girls, the increased } \\
\text { insecurity" which causes some par- } \\
\text { ents to keep girls at home.. }\end{array}$ \\
\hline
\end{tabular}

92 CEDAW, Concluding Observations: Nauru, CEDAW/C/NRU/CO/1-2, 22 November 2017, para. 42. 
TABLE 3 Vulnerability in the Receiving Country (contd)

Vulnerability Source $\quad$ Vulnerable Groups Reasons for Vulnerability
Context

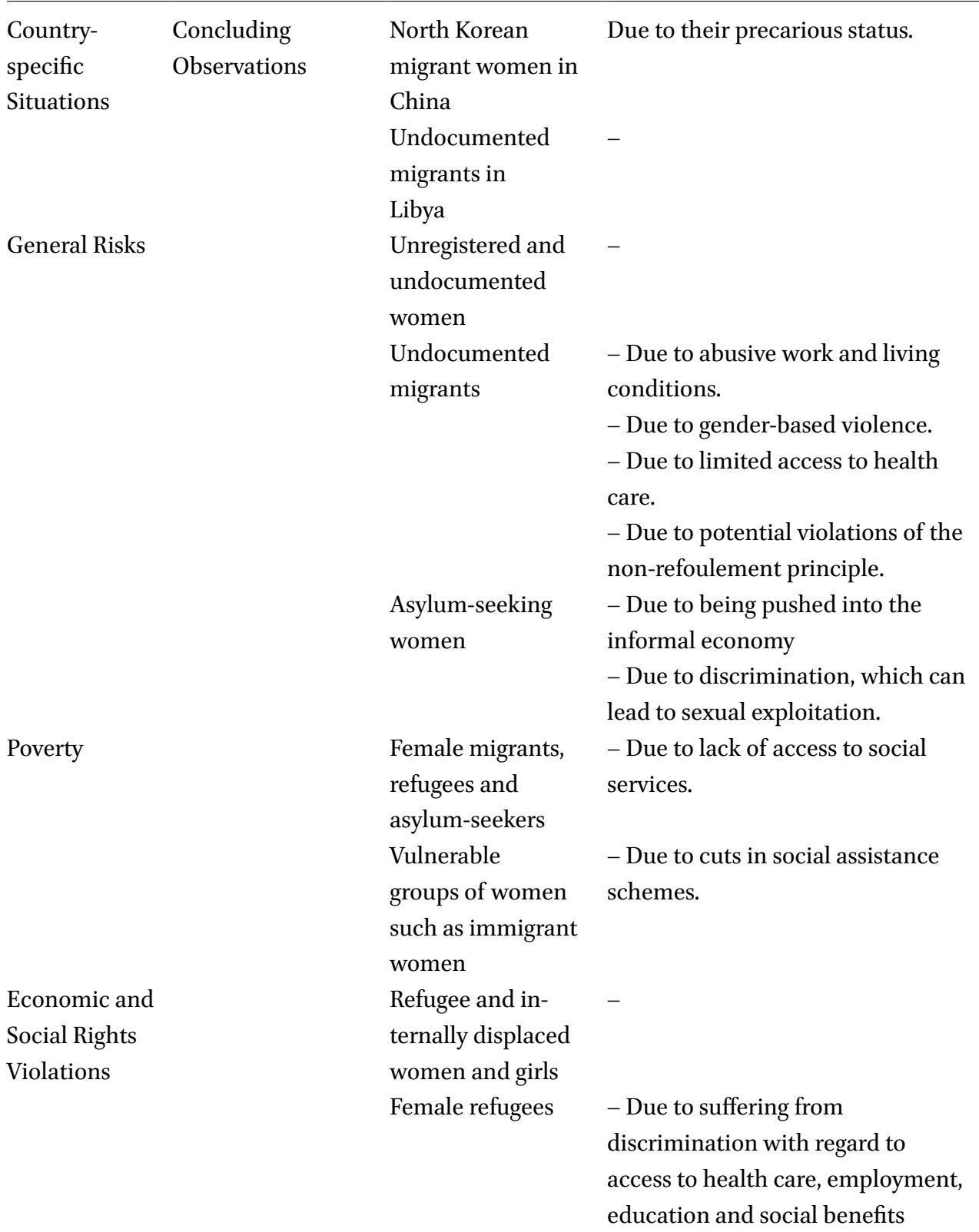




Vulnerability Source $\quad$ Vulnerable Groups Reasons for Vulnerability
Context

\begin{tabular}{|c|c|c|}
\hline & $\begin{array}{l}\text { Refugees, asylum- } \\
\text { seeking and dis- } \\
\text { placed women }\end{array}$ & $\begin{array}{l}\text { - Due to being at risk of multiple } \\
\text { discrimination. } \\
\text { - Due to stereotypical } \\
\text { attitudes. } \\
\text { - Due to difficulties in accessing } \\
\text { social services and obtaining } \\
\text { employment in line with } \\
\text { their skills. }\end{array}$ \\
\hline $\begin{array}{l}\text { Residence } \\
\text { Status }\end{array}$ & Migrant women & $\begin{array}{l}\text { - Due to the difficulties they } \\
\text { encounter with regard to obtaining a } \\
\text { residence permit. }\end{array}$ \\
\hline $\begin{array}{l}\text { Risk of } \\
\text { Domestic }\end{array}$ & $\begin{array}{l}\text { Female migrants, } \\
\text { refugees and }\end{array}$ & - \\
\hline Violence & asylum-seekers & \\
\hline Detention & $\begin{array}{l}\text { Refugee and asylum- } \\
\text { seeking women and } \\
\text { girls }\end{array}$ & $\begin{array}{l}\text { Due to limited access to basic } \\
\text { services and problematic overall } \\
\text { safety and security. }\end{array}$ \\
\hline
\end{tabular}

To summarise, the CEDAW Committee identifies several contexts that can contribute to the vulnerability of forced migrant women and girls in the receiving country. These can be either country-specific, related to general risks or related to specific issues. The Committee does not always provide the reasons for these vulnerabilities. Yet, when it does, the explanations are usually related to structural issues such as discrimination, limited social security schemes or abusive work or living conditions while the role of gender as such is not explicitly mentioned.

None of the vulnerability references explicitly mention the universal notion of vulnerability. The CEDAw Committee refers to the vulnerability of forced migrant women and girls in a variety of different contexts. It sometimes distinguishes between different gradations of vulnerability: all forced migrant women and girls are vulnerable but some of them are even more vulnerable than others. In some instances the Committee elaborates upon some of the reasons that contribute to this vulnerability. In such instances, these reasons relate to structural factors such as discrimination, gender roles or stereotyping. 
However, many vulnerability references by the Committee lack a clear argument about the reasons for this vulnerability.

\section{State Obligations related to the CEDAW's Identification of the Vulnerability of Forced Migrant Women and Girls}

This section focuses on the state obligations that the CEDAW Committee attaches to the identification of forced migrant women and girls as vulnerable. This does not necessarily reflect all state obligations towards forced migrant women and girls but merely those which are directly and explicitly linked to vulnerability. The Committee does not provide a comprehensive overview of the state obligations it attaches to the vulnerability label. Yet, it refers to a number of specific measures to be undertaken by state parties in order to mitigate the vulnerability of forced migrant women and girls.

One state obligation with regard to the vulnerability of forced migrant women and girls is of a more general nature and, in being linked to a core obligation, is broadly applicable to all other vulnerability references: General Recommendation 28 considers refugee, asylum-seeking and migrant women to be particularly vulnerable to discrimination through civil and penal laws. ${ }^{93}$ In light of the core obligation to eliminate discrimination, the Committee therefore obligates state parties to ensure the enforceability of the CEDAW in their domestic legal systems. ${ }^{94}$ In addition, several state obligations linked to vulnerability emerge in relation to the different phases of the migration process.

\subsection{State Obligations derived from Vulnerability in the Country of Origin}

The Committee attaches extensive state obligations to the vulnerability of forced migrant women and girls in the country of origin. With regard to health issues, General Recommendation 24 obliges state parties to pay attention to the health needs of refugee and internally displaced women and girls and to take appropriate measures to ensure that health services are sensitive to the needs of women with mental health issues since they are particularly vulnerable during conflict-induced displacement. ${ }^{95}$ The Committee does not further specify what those appropriate measures would be and leaves considerable room for state parties to interpret this obligation. However, General Recommendation 30 is more specific and asserts that, in order to mitigate the vulnerability

93 CEDAW, General Recommendation 28, para. 31.

94 Ibid.

95 CEDAW, General Recommendation 24, para. 25; CEDAW, General Recommendation 28, para. 31 . 
of women and girls to HIV/AIDS, state parties should ensure access to basic health services and information, which should include the prevention, care, support and treatment of HIV. ${ }^{96}$

As regards the vulnerability of women and girls to forced displacement and their vulnerability due to displacement, General Recommendation 30 holds that states should take preventive measures against forced displacement, counteract discrimination, facilitate meaningful inclusion and participation in decision-making processes, ensure equal access to services, protect and prevent gender-based violence, work towards socio-economic and livelihood opportunities for forced migrant women and girls and ensure that the forced migration situation is adequately addressed. ${ }^{97}$

With regard to climate change and natural disasters, General Recommendation 27 underlines that the vulnerability of elder forced migrant women should be addressed by protecting them through appropriate gender- and age-sensitize laws and policies. ${ }^{98}$

Although two Concluding Observations identify reasons which make forced migrant women and girls vulnerable due to negligence by the state, no direct obligations are attached to this identification. The table below summarizes these findings Table 4 .

In conclusion, the Committee outlines several structural deficits such as discrimination and poverty which increase the vulnerability of forced migrant women and girls in relation to armed conflicts and natural disasters and attaches several specific state obligations to this identification of vulnerability. While some of these measures merely focus on basic relief and access to essential services, others are of a more structural nature and emphasize the

TABLE 4 Vulnerability-related State Obligations for the Country of Origin

Source Vulnerable Groups Obligation

General

Recommendations

$\begin{array}{ll}\text { Women and girls } & \begin{array}{l}\text { Ensuring access to basic health } \\ \text { services and information, which } \\ \text { should include HIV prevention, } \\ \text { treatment, care and support. } \\ \text { Taking appropriate measures to }\end{array}\end{array}$

health issues ensure health services are sensitive

to their needs.

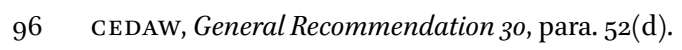

97 Ibid., para. 57 .

98 CEDAW, General Recommendation 27, para. 50.
} 
TABLE 4 Vulnerability-related State Obligations for the Country of Origin (contd)

\begin{tabular}{ll}
\hline Vulnerable Groups & Obligation \\
\hline Internally & - Paying attention to the health \\
displaced and & needs of these women and girls. \\
refugee women & - Taking preventive measures against \\
& forced displacement, counteract \\
& discrimination. \\
& - Facilitating meaningful inclusion \\
& and participation in decision-making \\
& processes. \\
& - Ensuring equal access to services. \\
& - Protecting and preventing gender- \\
& based violence. \\
& - Working towards socio-economic \\
& and livelihood opportunities. \\
& - Ensuring that the forced migration \\
& situation is adequately addressed. \\
& - Protecting them through appropri- \\
& ate gender- and age-sensitize laws \\
& and policies. \\
&
\end{tabular}

importance of facilitating the participation and inclusion of forced migrant women and girls in decision-making and planning as well as the need to adopt laws and policies that take the gender- and age-related vulnerabilities of forced migrant women and girls into account. These elements could be emphasized more prominently and explicitly so as to instigate meaningful changes in the human rights' protection of forced migrant women and girls. Nevertheless, the Committee's approach may be a valuable starting point from the perspective of the notion of universal vulnerability since it identifies specific state obligations to address structural deficits and hence contributes to strengthening the role of the state as a resilience-building institution.

\subsection{State Obligations derived from Vulnerability with regard to Trafficking and during Transit}

The Committee suggests several specific actions that the state party should undertake to mitigate the vulnerability of forced migrant women and girls during transit and trafficking. General Recommendation 30 recommends a number of measures to state parties in order to mitigate the vulnerability of 
forced migrant women and girls to exploitation and trafficking. ${ }^{99}$ These measures should include counteracting and prosecuting trafficking and related human rights violations, adopting a zero tolerance policy for sexual exploitation and abuse, providing training on how to identify and protect vulnerable women and girls, adopting a comprehensive gender-sensitive and rights-based migration policy and cooperating with other countries on the issue. 100

The Concluding Observations also refer to a number of state obligations that can mitigate the vulnerability to trafficking during transit. As such, several Concluding Obligations emphasize that the "root causes" of trafficking and, especially, the economic situation of women and girls in the context of forced migration should be addressed so as to limit the vulnerability to trafficking and exploitation. ${ }^{101}$ For this reason, state parties should create income-generating activities for women by ensuring their access to loans and to economic and educational opportunities for earning money. ${ }^{102}$ In addition, the Committee calls for more concrete measures for the protection of female refugees, asylumseekers and migrants from trafficking. Several countries are asked to adopt a national plan of action, raising awareness, training law enforcement officials and establishing mechanisms for the early identification of victims of trafficking. ${ }^{103}$ Moreover, the Committee emphasizes the importance of analyzing the reasons which lead to the involvement of non-national women in prostitution and of strengthening measures to address these reasons in order to mitigate the vulnerability to trafficking. ${ }^{104}$ These findings are summarized in the table below Table 5 .

\footnotetext{
99 CEDAW, General Recommendation 30, para. 40.

$100 \quad$ Ibid., para. 41.

101 CEDAW, 2007 Concluding Observations: Azerbaijan, para. 20; CEDAW, Concluding Observations: Azerbaijan, CEDAW/C/AZE/CO/4, 7 August 2009, para. 24; CEDAW, Concluding Observations: Philippines, CEDAW/C/PHL/CO/7-8, 25 July 2016, para. 28(c); CEDAW, Concluding Observations: Iceland, CEDAW/C/ISL/CO/7-8, 10 March 2016, para. 24(d); CEDAW, Concluding Observations: Barbados, CEDAW/C/BRB/CO/5-8, 24 July 2017, para. 26(c).

102 CEDAw, Concluding Observations: Djibouti, para. 23e; CEDAw, Concluding Observations: Mozambique, para. 27; CEDAw, Concluding Obserations: Nepal, para. 22(e); CEDAW, Concluding Observations: Indonesia, CEDAW/C/IDN/CO/5, 10 August 2007, para. 25; CEDAW, Concluding Observations: Philippines, CEDAW/C/PHI/CO/6, 25 August 2006, para. 20.

103 CEDAW, Concluding Observations: Ethiopia, CEDAW/C/ETH/CO/6-7, 27 July 2011, para. 24; CEDAW, Concluding Obserations: Djibouti, para. 22; CEDAW, Concluding Observations: Indonesia, para. 25; CEDAw, Concluding Observations: Iceland, para. 19(c); CEDAw, Concluding Observations: Paraguay, CEDAW/C/PRY/CO/7, 22 November 2017, para. 23.

104 CEDAW, Concluding Observations: Croatia, CEDAW/C/HRV/CO/4-5, 28 July 2015, para. 20(g); CEDAW, Concluding Observations: Denmark, CEDAW/C/DNK/CO/8, 11 March 2015, para. 21.
} 
TABLE 5 Vulnerability-related State Obligations with regard to Trafficking

\begin{tabular}{|c|c|c|}
\hline Source & Vulnerable Groups & Obligation \\
\hline General & Women and girls & - Counteracting and prosecut- \\
\hline \multirow[t]{9}{*}{ Recommendations } & $\begin{array}{l}\text { fleeing from conflict } \\
\text { zones }\end{array}$ & $\begin{array}{l}\text { ing trafficking and related hu- } \\
\text { man rights violations. }\end{array}$ \\
\hline & & $\begin{array}{l}\text { - Adopting a zero tolerance } \\
\text { policy for sexual exploitation } \\
\text { and abuse. }\end{array}$ \\
\hline & & - Providing training on how to \\
\hline & & identify and protect vulnerable \\
\hline & & women and girls. \\
\hline & & - Adopting a comprehensive \\
\hline & & gender-sensitive and rights- \\
\hline & & based migration policy. \\
\hline & & $\begin{array}{l}\text { - Cooperating with other coun- } \\
\text { tries on the issue. }\end{array}$ \\
\hline \multirow{6}{*}{$\begin{array}{l}\text { Concluding } \\
\text { Observations }\end{array}$} & Women & Improving income-generating \\
\hline & & $\begin{array}{l}\text { and educational opportunities } \\
\text { for women. }\end{array}$ \\
\hline & $\begin{array}{l}\text { Female refugees, } \\
\text { asylum-seekers and }\end{array}$ & $\begin{array}{l}\text { Adopting a national plan of ac- } \\
\text { tion, raising awareness, training }\end{array}$ \\
\hline & migrants & $\begin{array}{l}\text { law enforcement officials and } \\
\text { establishing mechanisms for the } \\
\text { early identification of victims of } \\
\text { trafficking. }\end{array}$ \\
\hline & Non-national women & Analyze the reasons leading to \\
\hline & involved in prostitution. & $\begin{array}{l}\text { their involvement in prostitution } \\
\text { and strengthen mechanisms to } \\
\text { counteract these reasons. }\end{array}$ \\
\hline
\end{tabular}

This section demonstrated that states should mitigate the vulnerability of forced migrant women and girls in relation to trafficking through the adoption of adequate policies and laws and through improvements in the security and economic situation of women and girls. Once again, the Committee focuses on the structures within which women and girls are rendered vulnerable rather than attempting to mitigate their vulnerability as women. This approach seems to be in line with the notion of universal vulnerability in thoroughly 
understanding the mutual influences between the embodied and embedded nature of vulnerability. Yet, despite this attention to the disadvantages of women and girls, the specific measures to mitigate this disadvantage could be more extensive and could place more emphasis on the need for resilience-building.

\subsection{State Obligations derived from Vulnerability during the Asylum Procedure}

The CEDAW Committee underlines that reception arrangements for forced migrant women and girls should be gender-sensitive so as to adequately cater to their specific needs related to experiences of trauma, violence or exploitation. ${ }^{105}$ Detention should also only take place if unavoidable. ${ }^{106}$ Border police and immigration officials should be provided with gender-sensitive training in order to adequately identify and address vulnerable women and girls. ${ }^{107}$

This is also confirmed in several Concluding Observations. ${ }^{108}$ The Committee proposes in several instances that the vulnerability of forced migrant women and girls can be mitigated by applying a gender-sensitive approach in the asylum procedure. ${ }^{109}$ For example, the Committee points out to Belgium that women identified as vulnerable should receive assistance from female public officials and female interpreters during the asylum procedure in order to allow them to talk about sensitive topics such as sexual abuse. ${ }^{110}$ The Committee instructs Nauru that forced migrant women and girls who experienced gender-based violence should have access to free legal aid and the perpetrators should be brought to justice. ${ }^{111}$ Furthermore, Italy is encouraged to provide clear guidelines, standards and procedures to identify and adequately assist vulnerable forced migrant women and girls. ${ }^{112}$ The Committee also emphasizes Argentina's general obligation to fill protection gaps with regard to forced migrant women and girls. ${ }^{113}$

\footnotetext{
105 CEDAW, General Recommendation 32, para. 34.

106 Ibid.

107 CEDAW, General Recommendation 3o, para. 41(b).

108 CEDAW, Concluding Observations: Argentina, para. 46; CEDAW, Concluding Observations: Nepal, para. 46 .

109 CEDAW, Concluding Observations: Austria, para. 30; CEDAW, Concluding Observations: Argentina, para. 46; CEDAW, Concluding Observations: China, para. 34; CEDAW, Concluding Observations: Nepal, para. 42(b); CEDAW, Concluding Observations: Belgium, paras. 37-38.

110 CEDAW, Concluding Observations: Belgium, para. 37.

111 CEDAW, Concluding Observations: Nauru, para. 43.

112 CEDAW, Concluding Observations: Italy, para. 15(a).

113 CEDAW, Concluding Observations: Argentina, para. 45.
} 
As pointed out earlier, the Committee's Views which refer to the vulnerability of forced migrant women and girls remain limited. Yet, the dissenting opinion attached to the Views in Zhen Zhen Zheng v. the Netherlands is insightful with regard to potential state obligations that arise during the asylum procedure due to vulnerability. It is argued that the communication should have been declared admissible, inter alia because of the applicant's situation as a vulnerable person, and that the vulnerable status of trafficked persons should be taken into account in asylum procedures. ${ }^{114}$ States should train border guards, police and immigration officers to allow the early identification of victims of trafficking and should provide guidelines for interviewing vulnerable individuals. ${ }^{115}$ The findings are summarized in the table below.

TABLE 6 Vulnerability-related State Obligations during the Asylum Procedure

\begin{tabular}{|c|c|c|}
\hline Source & Vulnerable Groups & Obligation \\
\hline General & Victims of sexual abuse & - Adopting gender-sensitive \\
\hline \multirow[t]{6}{*}{ Recommendations } & and exploitation, of & reception arrangements. \\
\hline & trauma and torture or & - Taking into account special \\
\hline & ill-treatment and of other & needs. \\
\hline & particularly vulnerable & - Administering detention only if \\
\hline & groups of women and girls & unavoidable. \\
\hline & $\begin{array}{l}\text { Vulnerable women and } \\
\text { girls }\end{array}$ & $\begin{array}{l}\text { Providing gender-sensitive train- } \\
\text { ing for border police and immigra- } \\
\text { tion officials. }\end{array}$ \\
\hline \multirow{10}{*}{$\begin{array}{l}\text { Concluding } \\
\text { Observations }\end{array}$} & Vulnerable women and & Providing gender-sensitive train- \\
\hline & girls & $\begin{array}{l}\text { ing for border police and immigra- } \\
\text { tion officials. }\end{array}$ \\
\hline & Vulnerable women & Adopting a gender-sensitive \\
\hline & & $\begin{array}{l}\text { approach in the asylum proce- } \\
\text { dure, e.g. by providing assistance }\end{array}$ \\
\hline & & through female public officials \\
\hline & & and female interpreters. \\
\hline & Refugee and asylum- & Ensuring access to free legal aid \\
\hline & seeking women and girls & and bringing perpetrators to \\
\hline & who are victims of gender- & justice. \\
\hline & based violence & \\
\hline
\end{tabular}

114 CEDAw, Zhen Zhen Zheng v. the Netherlands, Communication No. 15/2007, 27 October 2008, paras. 8.1 and 9.1.

115 Ibid., para. 9.1. 


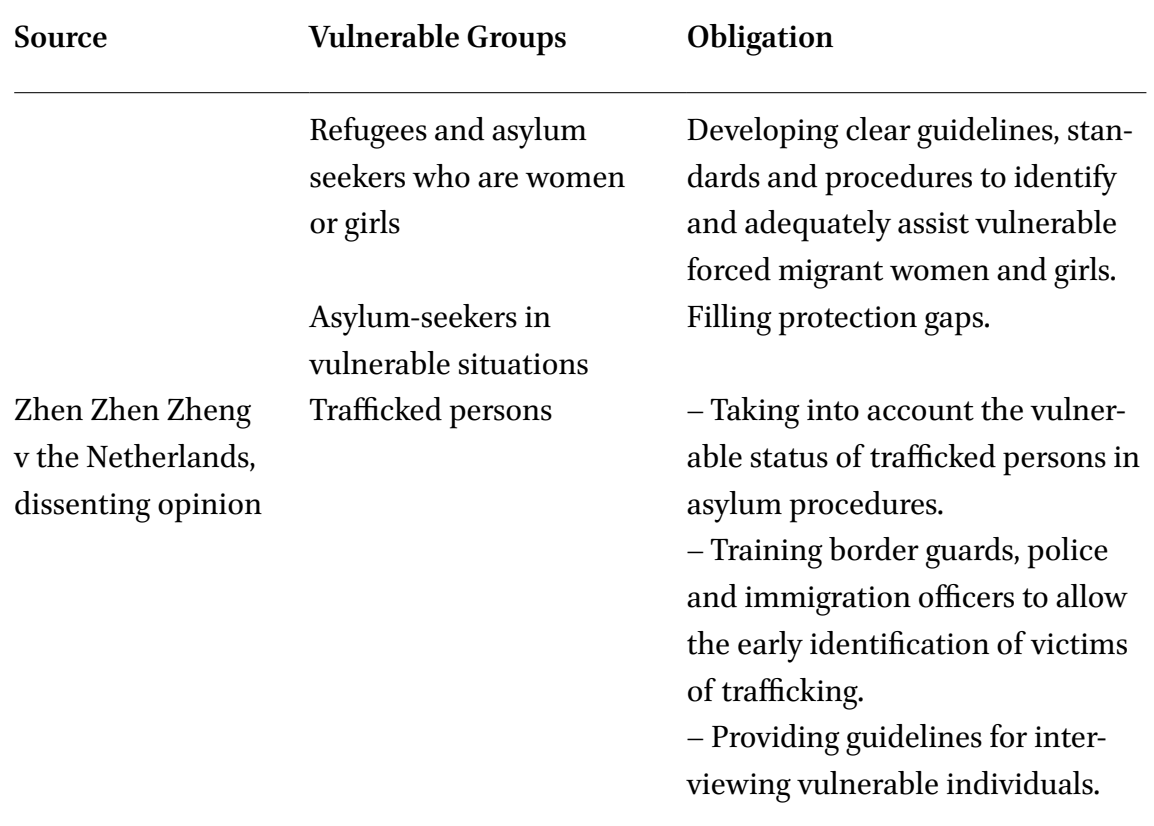

The foregoing discussion showed that several state obligations arise from the vulnerability of forced migrant women and girls with regard to the asylum procedure. The Committee suggests concrete measures which can mitigate the vulnerability of forced migrant women and girls during the asylum procedure. Measures such as avoiding detention, using female officials and providing training on vulnerability identification all seem to support resilience-building as imagined by the notion of universal vulnerability. However, from the notion of universal vulnerability perspective, the Committee's suggestions for mitigating the vulnerability of forced migrant women and girls during the asylum procedure are insufficient for building resilience in at least two respects. First, the Committee could have paid more attention to the (migration) laws and policies which might contribute to the vulnerability of forced migrant women and girls. These laws and policies are the central framework that shapes the vulnerability experience of forced migrant women and girls during the asylum procedure. Second, the Committee neglects the fact that, in order to benefit from any resilience-building measures during the asylum procedure, a person first has to be able to perform his or her vulnerability so as to be eligible. Hence, more attention should have been paid to state obligations to adequately identify vulnerability in the first place. ${ }^{116}$

116 See, e.g. Flegar and Veys, 'De Europese Verplichtingen'. 


\subsection{State Obligations derived from Vulnerability in the Receiving Country}

The CEDAW Committee identifies state obligations on the basis of the vulnerability of forced migrant women and girls in the receiving country in relation to several issues. Nonetheless, the state obligations contained in the General Recommendations remain limited and focus only on two issues: education and statelessness. As regards education, General Recommendation 36 highlights that states should ensure that all disadvantaged women and girls, including migrants, have access to education and safety and that a mandatory dress-code does not impede this access. ${ }^{117}$ Regarding statelessness, the Committee holds that vulnerable women need to be protected by ensuring that the measures to prevent statelessness are applied to all migrant women and by providing them with the individual documentation that is necessary to exercise their legal rights. ${ }^{118}$

The Concluding Observations are more explicit and consider the effective realization of economic, social and cultural rights as an important mitigating factor for the vulnerability of forced migrant women and girls in the receiving country. Several Concluding Observations suggest that state parties should take targeted measures to improve the access of vulnerable migrant women to economic, social and cultural rights. ${ }^{119}$ Lebanon is encouraged to facilitate access to health care so as to mitigate the vulnerability of refugee women. ${ }^{120}$ Several Concluding Observations emphasize that a good integration policy (which includes access to the labour market, education and skill training) is important for mitigating the vulnerability of forced migrant women and girls and for advancing formal equality. ${ }^{121}$ The Committee also states that social assistance programs should meet the needs of vulnerable groups of women, including immigrant women. Hence, Canada, for instance, is urged to establish minimum standards for social assistance programs ${ }^{122}$ and Sweden should

\footnotetext{
117 CEDAW, General Recommendation 36, para. 46.

118 CEDAW, General Recommendation 30, para. 61.

119 CEDAW, 2007 Concluding Observations: Azerbaijan, para. 38; CEDAW, Concluding Observations: Bangladesh, CEDAW/C/BGD/CO/8, 25 November 2016, paras. 40-41.

120 CEDAW, Concluding Observations Lebanon, para. 40; CEDAW, Concluding Observations: Nauru, para. 43 .

121 CEDAW, Concluding Observations: Sweden, para. 38; CEDAW, Concluding Observations: Philippines, CEDAW/C/PHI/CO/6, 25 August 2007, para. 20; CEDAW, 2007 Concluding Observations: Azerbaijan, paras. 20 and 38; CEDAW, Concluding Observations: Austria, para. 30; CEDAW, Concluding Observations: Canada, CEDAW/C/CAN/CO/8-9, 25 November 2016, paras. 46 and 47 .

122 CEDAW, 2008 Concluding Observations: Canada, para. 14.
} 
ensure effective access to social services for "immigrant, refugee and minority women". ${ }^{123}$ Moreover, Italy is encouraged to provide adequate services to refugees and asylum seekers that are placed in administrative detention - especially to those who are vulnerable. ${ }^{124}$

Additionally, the Committee considers awareness-raising to be an important aspect that can mitigate vulnerability. Several Concluding Observations emphasize that migrant women should be made aware of the social rights and services that they are entitled to in order to mitigate their vulnerability. ${ }^{125}$ In order to increase awareness, the Committee also specifically recommends to El Salvador to introduce educational programs focused on the rights that migrant women are entitled to. ${ }^{126}$

Furthermore, several Concluding Observations underline the significance of the political and cultural participation of vulnerable forced migrant women and girls. ${ }^{127}$ As such, Australia is urged to ensure the equal participation of vulnerable forced migrant women and girls and to put them in leadership and decision-making positions. ${ }^{128}$ Other measures the Committee encourages to mitigate vulnerability include adopting gender-specific policies, ${ }^{129}$ protecting women against domestic violence through a national plan of action, ${ }^{130}$ and registering undocumented women and providing them with documents in order to protect them from refoulement. ${ }^{131}$ The table below summarizes these findings Table 7 .

The Committee is particularly detailed with regard to the state obligations which arise from the vulnerability of forced migrant women and girls in the

\footnotetext{
123 CEDAW, Concluding Observations: Sweden, para. 39.

124 CEDAW, Concluding Observations: Italy, para. 16(c).

125 CEDAW, Concluding Observations: Ecuador, para. 23; CEDAW, Concluding Observations: Germany, CEDAW/C/DEU/6, 12 February 2009, para. 60.

126 CEDAw, Concluding Observations: El Salvador, CEDAW/C/SLV/CO/7, 7 November 2008, paras. 11-12.

127 CEDAW, 2009 Concluding Observations: Germany, para. 59; CEDAW, 2009 Concluding Observations: Azerbaijan; CEDAW, Concluding Observations: Australia, CEDAW/C/AUL/CO/7, 30 July 2010, para. 26; CEDAW, Concluding Observations: Tajikistan, CEDAW/C/TJK/CO/4-5, 29 October 2013, para. 31.

128 CEDAW, Concluding Observations: Australia, para. 26.

129 CEDAW, 2009 Concluding Observations: Armenia, para. 37.

130 CEDAW, 2009 Concluding Observations: Germany, para. 59; and CEDAW, Concluding Observations: Sweden, para. 38.

131 CEDAW, Concluding Observations: Ecuador, para. 27.
} 
TABLE 7 Vulnerability-related State Obligations for the Receiving Country

\begin{tabular}{|c|c|c|}
\hline Source & Vulnerable Groups & Obligation \\
\hline \multirow[t]{2}{*}{$\begin{array}{l}\text { General } \\
\text { Recommendations }\end{array}$} & $\begin{array}{l}\text { Disadvantaged groups of } \\
\text { women and girls, espe- } \\
\text { cially migrants }\end{array}$ & $\begin{array}{l}\text { - Ensuring the adequate provision of educa- } \\
\text { tion and safety. } \\
\text { - Ensuring that a mandatory dress code } \\
\text { does not hamper access to education. }\end{array}$ \\
\hline & $\begin{array}{l}\text { Women vulnerable to } \\
\text { statelessness }\end{array}$ & $\begin{array}{l}\text { - Ensuring that the measures to prevent } \\
\text { statelessness are applied to all migrant } \\
\text { women. } \\
\text { - Providing migrant women with the indi- } \\
\text { vidual documentation that is necessary to } \\
\text { exercise their legal rights. }\end{array}$ \\
\hline \multirow{10}{*}{$\begin{array}{l}\text { Concluding } \\
\text { Observations }\end{array}$} & Vulnerable migrant & Taking targeted measures to improve access \\
\hline & women & to economic, social and cultural rights. \\
\hline & $\begin{array}{l}\text { Female asylum seekers, } \\
\text { refugees and migrants }\end{array}$ & $\begin{array}{l}\text { Facilltating access to health care } \\
\text { Providing a good integration policy }\end{array}$ \\
\hline & Immigrant women & $\begin{array}{l}\text { Establishing minimum standards for social } \\
\text { assistance programs. }\end{array}$ \\
\hline & $\begin{array}{l}\text { Immigrant, refugee and } \\
\text { minority women }\end{array}$ & Ensuring effective access to social services. \\
\hline & Migrant women & $\begin{array}{l}\text { - Making them aware of their rights and } \\
\text { services they are entitled to. } \\
\text { - Introducing educational programs } \\
\text { focused on these rights. }\end{array}$ \\
\hline & $\begin{array}{l}\text { Forced migrant women } \\
\text { and girls }\end{array}$ & $\begin{array}{l}\text { - Putting them in leadership ad decision- } \\
\text { making positions. } \\
\text { - Encouraging their political and cultural } \\
\text { participation. }\end{array}$ \\
\hline & Women & $\begin{array}{l}\text { - Adopting gender-specific policies. } \\
\text { - Protecting them against domestic vio- } \\
\text { lence through a national plan of action. }\end{array}$ \\
\hline & Undocumented women & $\begin{array}{l}\text { Providing them with documents in order to } \\
\text { protect them from refoulement. }\end{array}$ \\
\hline & $\begin{array}{l}\text { Refugees and asylum } \\
\text { seekers in administrative } \\
\text { detention }\end{array}$ & $\begin{array}{l}\text { Providing adequate services, especially to } \\
\text { those who are vulnerable. }\end{array}$ \\
\hline
\end{tabular}


receiving country. While the General Recommendations address only obligations with regard to education and statelessness, the Concluding Observations provide an extensive account of measures that can or should be taken by states to mitigate the vulnerability of forced migrant women and girls. The Committee focuses specifically on the access to economic, social and cultural rights, awareness-raising, the facilitation of political and cultural participation, the adoption of gender-specific policies and the protection from violence and refoulement. These measures are in line with the resilience-building approach suggested by the notion of universal vulnerability: they clearly attach a role to the state to not only protect human rights but to also actively ensure their realization by supporting state and societal institutions in a way that can mitigate the vulnerability of forced migrant women and girls. However, issues of marginalization and discrimination do not seem to be addressed extensively by the Committee. Moreover, it should be noted that the Committee does not always seem equally keen to recommend measures for the mitigation of vulnerability. With regard to the status of North Korean migrant women in China as "illegal aliens", for example, the Committee merely calls upon China to "review this situation". 132

In conclusion to section 4, the CEDAW Committee clearly attaches state obligations to the identification of vulnerability of forced migrant women and girls but it does not always recommend detailed measures that a state should undertake when vulnerability is at stake. Although the General Recommendations do not provide a comprehensive overview of the measures required to protect forced migrant women and girls during the different phases of the migration process, several Concluding Observations suggest extensive lists of measures to be taken by states and institutions to contribute to the resilience of forced migrant women and girls.

The Committee's suggested measures seem to partially reflect the notion of universal vulnerability's understanding of a responsive state that engages in the mitigation of vulnerability. By not simply considering women and girls as vulnerable per se but as vulnerable due to the failure of the laws, policies and institutions that should ensure their resilience, the Committee seems to acknowledge vulnerability as both embodied and embedded along similar lines as the notion of universal vulnerability.

However, the Committee's approach is far from perfect. The fact that the suggested measures to mitigate vulnerability are primarily mentioned in the Concluding Observations, the lack of an explicit emphasis on resilience,

132 CEDAW, Concluding Observations: China, para. 34. 
the neglect of the fundamental role of migration laws and policies and the limited attention being paid to the mitigation of discrimination and marginalization as crucial elements of resilience-building still leave much to be desired if the vulnerability labelling of the CEDAW Committee is to add anything substantial to the protection of the human rights of forced migrant women and girls.

\section{5 \\ Discussion and Conclusions from a Universal Vulnerability Perspective}

This article focused on the CEDAW Committee's understanding of the vulnerability of forced migrant women and girls and the state obligations that appear to flow from any references to their vulnerability. This section discusses the CEDAW Committee's work on the vulnerability of forced migrant women and girls in light of the notion of universal vulnerability and answers the question of the extent to which the CEDAW Committee's identification of vulnerability with regard to forced migrant women and girls contributes to the protection of human rights. The section first investigates whether and to what extent the Committee's approach reflects an understanding of vulnerability as universal and particular and the effect this approach has on stigmatization. Subsequently, the discussion turns to the question of state obligations and the extent to which they reflect an understanding of the state as a resiliencebuilding institution.

The CEDAW Committee does not (yet) seem to have adopted a coherent approach with regard to the identification of vulnerability during the forced migration process. The Committee refers to the vulnerability of forced migrant women and girls in a variety of different contexts. In some instances, the Committee distinguishes between different gradations of vulnerability: all forced migrant women and girls are vulnerable but some of them are even more vulnerable than others. Moreover, the Committee sometimes provides reasons for the vulnerability of specific individuals or groups while on other occasions it merely attaches the label of vulnerability without providing any further explanation. Where reasons are provided, these reasons usually concern structural factors, such as discrimination, gender roles or stereotyping.

At first sight, none of the Committee's vulnerability labels for forced migrant women and girls explicitly refer to any universal notion of vulnerability. Yet, when understanding the universal vulnerability notion as entailing an embodied and an embedded dimension, the Committee's approach exhibits some overlap with the notion. The CEDAW Committee understands vulnerability as embodied by identifying gender and health issues as being relevant to the 
vulnerability of forced migrant women and girls. By linking this embodied vulnerability, at least incidentally, to structural deficits that aggravate or make this vulnerability relevant in the first place the Committee equally acknowledges the embedded nature of vulnerability. While the Committee's approach is not (yet) entirely in line with the universal vulnerability notion, the references to structural issues are particularly promising for the protection of human rights: they emphasize and uncover the role of societal institutions in the mitigation of vulnerability. Rather than stigmatizing the group of forced migrant women and girls as vulnerable per se, the attention to structural deficits that make the vulnerability of this group relevant in the first place nuances the group-based vulnerability label. Moreover, the references to structural elements provide important indicators for the resilience-building of the groups or individuals identified as vulnerable.

As regards the question of state obligations and resilience-building, the CEDAW Committee requires states to take specific actions to mitigate the vulnerability of forced migrant women and girls in several instances. However, the labelling of forced migrant women and girls as vulnerable does not automatically lead to state obligations and the Committee does not always recommend detailed measures that a state should undertake when vulnerability is at stake. Although the General Recommendations do not provide a comprehensive overview of the measures required to protect forced migrant women and girls during the different phases of the migration process, several Concluding Observations suggest extensive lists of measures to be taken by states and institutions in order to contribute to the resilience of forced migrant women and girls. These measures primarily relate to the realization of the human rights of forced migrant women and girls through facilitating their access to services and participation in decision-making as well as through awareness-raising and vulnerability-related trainings to state officials.

In light of the notion of universal vulnerability, the Committee's interpretation of state obligations in relation to the vulnerability of forced migrant women and girls exhibits several shortcomings. As such, there seems to be little acknowledgement of the role of societal actors and social institutions in the mitigation of the vulnerability of forced migrant women and girls. Moreover, the Committee's attention to the state's responsibility in addressing discrimination and marginalization as reasons of vulnerability remains limited. The Committee does not explicitly refer to the importance of resilience-building and seldom acknowledges the fundamental role of migration laws and policies for the vulnerability of forced migrant women and girls.

Simultaneously, the Committee's approach equally incorporates some of the elements which the notion of universal vulnerability considers important 
for resilience-building. The Committee emphasizes the primary responsibility of the state to provide the framework that allows other institutions to function in a way that can mitigate the vulnerability of forced migrant women and girls. Moreover, the Committee does not simply consider women and girls as vulnerable per se but as vulnerable due to the failure of the laws, policies and institutions that should ensure their resilience. In so doing, the Committee emphasizes the fundamental role of structural deficits for making forced migrant women and girls vulnerable in the first place.

Overall, the vulnerability label adopted by the CEDAW Committee is not (yet) entirely in line with what the theoretical notion of universal vulnerability promises for the realization of human rights. Nevertheless, the analysis demonstrated that vulnerability references can still foster the human rights protection of forced migrant women and girls since the vulnerability label draws specific attention to some of the human rights issues they face throughout the migration process.

In order to mitigate any stigmatizing effects of its vulnerability approach, the CEDAW Committee should reject the mere labelling of vulnerable groups more consistently and acknowledge the importance of identifying the reasons for why a group is considered vulnerable. Vulnerability references are most likely to contribute to the protection of human rights if the use of such references carefully considers any potentially stigmatizing effects. This does not necessarily preclude group-based references to vulnerability but it requires 1) the identification of vulnerability in relation to a specific context; 2) a clear explanation of the reasons for why this group is deemed vulnerable in the specific context; and 3) attention to the structural elements that hinder the resilience-building of the specific group. The Committee could emphasize the universal nature of vulnerability more explicitly in order to avoid singling out some human beings as weak or potential victims. In so doing, the mitigation of the vulnerability of forced migrant women and girls could be placed in a more constructive frame.

As regards resilience-building, viewing the issue of forced migration and, in particular, the position of women and girls in this respect through the vulnerability lens allows uncovering the issues that should be of absolute priority for states in order to abide by their human rights obligations. Although the CEDAW Committee's understanding of vulnerability mitigation leaves much to be desired, the emphasis placed on structural deficits and dysfunctions and the role of laws, policies and institutions for the building of resilience seem a promising starting point for an improved protection of the human rights of forced migrant women and girls. 
Hence, despite the remaining pitfalls from the perspective of the notion of universal vulnerability, the CEDAW Committee's vulnerability label for forced migrant women and girls can contribute to clarifying state obligations and provides a human-centered criticism of how current migration laws and policies fail to mitigate, and sometimes even aggravate, vulnerability. Further research would be desirable in order to uncover and discuss how these findings also apply to contexts beyond forced migration in which the CEDAW Committee uses the vulnerability label to identify certain issues. It remains to be seen whether and to what extent the Committee is willing and able to develop a more coherent approach towards vulnerability. 